Pobrane z czasopisma Annales H - Oeconomia http://oeconomia.annales.umcs.pl Data: 26/04/2023 01:37:42

DOI:10.17951/h.2017.51.5.331

\begin{tabular}{lcc}
\hline \multicolumn{3}{c}{ A N N A L E S } \\
UNIVERSITATIS MARIAE CURIE-SKŁODOWSKA \\
LUBLIN - POLONIA \\
VOL. LI, 5 & SECTIO H \\
\hline
\end{tabular}

Lodz University of Technology. Faculty of Management and Production Engineering

IWONA WOJCIECHOWSKA-TORUŃSKA

iwona.wojciechowska-torunska@p.lodz.pl

\title{
Tax Progression vs Economic Growth \& Development Index (GDI)
}

Progresja podatkowa a Indeks Wzrostu i Rozwoju (GDI)

Keywords: public finance; taxation; progressive taxation; economic growth and development

Słowa kluczowe: finanse publiczne; stawki podatkowe; podatek progresywny; wzrost i rozwój gospodarczy

JEL Code: H21; H24; H23; D6; E6

\section{Introduction}

As theoretical economics as well as empirical researchers are far from any consensus related to the interactions between progressive taxation and economic growth, it is advisable to carry out further tests and analysis of this kind of issue. However, this paper is mainly motivated by different aspects. The vast majority of empirical research already performed has been focused on developed countries and primarily on the USA. The 2008 financial crisis redirected an interest to the emerging economies. In recent years, tax reforms were carried out in most EU countries. They were focused on reducing the tax burden [European Commission 2014, p. 314]. The EU as a whole still remains an area of "high taxation".

Qualities and quantities can be applied to the concept of qualitative growth and the phenomenon of development, which is related to growth. Like "growth", "development" is used today in two quite different senses - one qualitative, as used by the UN's Human Development Index (HDI), and the other - quantitative. The 
author's intention was to formulate the growth index that combines qualities and quantities of "growth" together in one concept. Moreover, the author's motivation is strengthened by the first Global Happiness Report issued in 2012 that redirected economic interest more to "economic development" than "economic growth" and focused on data concerning economic growth measures in 2012.

The main purpose of this article is to present correlation analyses of the average tax rate, the amount of tax brackets and the so-called economic "growth $\&$ development index" (GDI) in the "high taxed" and "low taxed" European countries. The article also tries to answer the question what the strength of correlation between analysed economic variables is.

The hypothesis is as follows: the more number of tax brackets in income progressive tax, the lower the growth \& development index.

In order for the purposes to be accomplished, this study proceeds as follows. The next section presents a review of the relevant empirical literature. Section 2 explains methodological issues and describes the data employed. Section 3 contains the empirical results, and the last section discusses the findings and summarizes the conclusions.

\section{Literature review}

A review of the public finance literature shows that the higher the level of economic growth the lower the tax rates [Lee, Gordon, 2005, p. 1228; Angelopoulos, Economides, Kammas, 2007, p. 2]. However, some economists believe that raising tax rates promotes economic growth [Garrison, Lee, 1992, p. 173; Engen, Skinner, 1992, p. 32; Mendoza, Milesi-Ferretti, Asea, 1997, p. 122; Padovano, Galli, 2001, p. 50; Piketty, Saez, Stantcheva, 2011, p. 36] and yet another group of experts are of the opinion that we should reduce the rates of income tax and increase the consumption tax rate [Konopczyński, 2012, p. 24]. Nowadays, still most OECD countries have very progressive individual income taxes with a large number of tax brackets and high top tax rates [see: OECD, 1986]. Bankman and Griffith [1987] in their article Social Welfare and the Rate Structure argued that the strongest argument for progressivity is that transferring income from richer to poorer individuals (through a combination of taxation and government spending), increases total welfare or utility in the society. The reason such transfers increase welfare is simple: additional money produces more utility for a poor person than a rich person. Since 1987, a number of commentators have added their views of how progressivity should impact the economic growth. These include both academics [e.g. Stiglitz, 1987, p. 993; Easterly, Rebelo, 1993, p. 450; Sarte, 1997, p. 165; Castañeda, Diaz-Gimenez, Rios-Rull, 1999, p. 5; Tanzi, Zee, 2000, p. 327] and policy makers [Li, Sarte, 2001, p. 21; U.S. Treasury, 2005, p. 21].

Tanzi and Zee [2000] write that the rate structure of the personal income tax is often the most convenient policy instrument for most governments in developing countries to underscore their commitments to social justice, and to gain political 
support for their policies. "Many developing countries attach great importance to maintaining some degree of nominal personal income tax rate progressivity by applying many rate brackets, and are reluctant to undertake personal income tax reforms". Li and Sarte [2001] observe that firstly, as the degree of tax progressivity increases, it is not clear that the share of tax revenue in GDP should rise and, in fact, it may even decline. Secondly, because more progressive tax systems are generally more distortional, they are also more likely to be associated with lower economic growth ceteris paribus. And again, the above observations have motivated the author to ask the question about the strength of correlation between average level of tax, amount of tax brackets and the so-called "growth \& development index" in European countries.

\section{Methodology and data}

Research methods used in the study are: unity-based normalization and Spearman's rank correlation analysis.

The tax data covered 28 EU countries plus Norway in 1995-2012. The high tax rate countries have average tax rates above the median amounted to 30.27. Low tax rate countries have average tax rates below the median. Among this group of countries were selected two groups of countries with the highest average tax rate and the lowest average tax rate ${ }^{1}$. Five countries were selected in each group to focus on the most extreme value of average tax rate. The next step in the study was to analyze the countries with the highest GDI in their groups due to the presence of tax progression.

The growth and development index formula and the average tax rates were calculated using the Eurostat and Pordata - the Database of Contemporary Portugal. Pordata was organized and developed by the Francisco Manuel dos Santos Foundation (created in 2009). Over sixty official agencies with particular emphasis on Statistics Portugal cooperate with Pordata.

The index of economic growth \& development (GDI) is an arithmetic mean of normalized measures of economic growth and economic development. The best recorded value within each index is 1 . The maximum value of the index of economic growth is 1 , and the lowest is 0 . The formula of growth \& development index $\left(\mathrm{GDI}_{\mathrm{n}}\right)$ is as follows:

$$
G D I_{n}=\frac{G N P_{n}+G D P_{n}+G D P \%_{n}}{3}
$$

where:

$\mathrm{n}-$ is the number of years during which economic growth is tested

\footnotetext{
1 Average tax rate has been calculated using the arithmetic mean taking into account the average tax rates in the three main taxes: PIT, CIT and VAT in the years from 1995 to 2012 based on Eurostat data [see: European Commission, 2014].
} 
$\mathrm{GDI}_{\mathrm{n}}$ - economic growth index in n-year

$\mathrm{GNP}_{\mathrm{n}}$ - normalized Gross National Product PPP in n-year

$\mathrm{GDP}_{\mathrm{n}}-$ normalized Gross Domestic Product per capita in n-year

$\mathrm{GDP} \%_{\mathrm{n}}$ - normalized real economic growth in n-year

The measures of economic growth are some qualitative and quantitative indexes of growth. The author was inspired by biologists' statement about economist: "economists recognise only money and cash flows, ignoring all other forms of fundamental wealth - all ecological, social, and cultural assets. The biological concept of development includes both quantitative and qualitative growth" [Capra, Hazel, 2009, p. 5].

Finally, the correlation analyses were conducted using Spearman's rank correlation coefficient (R). Spearman's correlation coefficient is a statistical measure of the strength of a monotonic relationship between paired data. Correlation is an effect size and so one can verbally describe the strength of the correlation using the following guide for the absolute value of:

$$
\begin{array}{ll}
- & 0.19 \text { "very weak", } \\
- & 0.20-0.39 \text { "weak", } \\
- & 0.40-0.59 \text { "moderate", } \\
- & 0.60-0.79 \text { "strong", } \\
- & 0.80-1.0 \text { "very strong". }
\end{array}
$$

A correlation study was conducted between selected variables such as the GDI, the average tax rate, and amount of tax brackets. For each correlation coefficient, $\mathrm{p}$-value $(\mathrm{P})$ statistics were calculated. A value of less than 0.05 indicates the presence of the required statistical significance.

\section{Results}

Relevant results are presented in Tab. 1. It shows GDI and income tax progression in group A of European countries.

Tab. 1. GDI $_{2012}$ index and the number of tax brackets in group A of European countries

\begin{tabular}{|l|c|c|c|c|}
\hline Country & $\begin{array}{c}\text { The average tax } \\
\text { rate in the years } \\
1995-2012(\%)\end{array}$ & $\begin{array}{c}\text { Number of rate } \\
\text { brackets }\end{array}$ & GDI $_{2012}$ & Ranking \\
\hline Denmark & 39.6 & 5.0 & 0.461 & 2 \\
\hline Belgium & 39.4 & 7.0 & 0.375 & 4 \\
\hline Germany & 36.6 & 3.0 & 0.384 & 3 \\
\hline Netherlands & 36.1 & 4.0 & 0.353 & 5 \\
\hline Norway & 35.3 & 3.0 & 0.762 & 1 \\
\hline Average & 37.4 & 4.4 & 0.467 & none \\
\hline
\end{tabular}

Source: own calculations based on: [European Commission, 2014; U.S. Treasury, 2005]. 
One can notice that the group of "high tax rate" countries was accompanied by the high degree of tax brackets and a high "economic growth \& development index". The highest GDI was in Norway (with 3 numbers of rate brackets) and in Denmark (with 5 numbers of rate brackets). The average GDI for "high tax rate" countries was 0.467 (Tab. 1). Tab. 2 presents low-average tax rates European countries and their GDI in 2012.

Tab. 2. Index $\mathrm{GDI}_{2012}$ and income tax progression in group B of EU countries

\begin{tabular}{|l|c|c|c|c|}
\hline \multicolumn{1}{|c|}{ Country } & $\begin{array}{c}\text { The average tax } \\
\text { rate in the years } \\
1995-2012\end{array}$ & GDI $_{2012}$ & $\begin{array}{c}\text { Number of rate } \\
\text { brackets }\end{array}$ & Ranking \\
\hline Latvia & 20.90 & 0.425 & lack & 1 \\
\hline Lithuania & 21.65 & 0.375 & lack & 2 \\
\hline Estonia & 22.20 & 0.227 & lack & 3 \\
\hline Bulgaria & 23.08 & 0.122 & lack & 5 \\
\hline Czech Republic & 23.43 & 0.120 & lack & none \\
\hline Average & 22.20 & 0.253 & lack & \\
\hline
\end{tabular}

Source: own calculations based on: [European Commission, 2014; U.S. Treasury, 2005].

The Czech Republic was a country in which GDI was the lowest and at the same time average tax rate was the highest in its group. Latvia is a country with the highest GDI and the lowest average tax rate in their group. It can be argued that in free-progression countries, the relationships of two variables - average tax rates and GDI - was inversely proportional.

Tab. 3 shows EU countries with the highest GDI and their ranking. It was surprising that the two countries Lithuania and Denmark had the same level of GDI, yet their average tax rates were extremely different. Accordingly, $21.65 \%$ and $39.4 \%$. Lithuania does not have a tax progression and Denmark has up to 7 tax brackets. The preliminary conclusion was: the size of GDI can be the same in "high tax rate" and "low tax rate" countries, regardless of the existence of tax progression.

Tab. 3. The EU countries with the highest $G \& D_{2012}$ index

\begin{tabular}{|l|c|c|c|c|}
\hline \multicolumn{1}{|c|}{ Country } & $\begin{array}{c}\text { The average tax } \\
\text { rate in the years } \\
1995-2012\end{array}$ & G\&D $_{2012}$ & $\begin{array}{c}\text { Number of rate } \\
\text { brackets }\end{array}$ & Ranking \\
\hline Latvia & 20.90 & 0.425 & lack & 3 \\
\hline Lithuania & 21.65 & 0.375 & lack & 4 \\
\hline Belgium & 39.40 & 0.375 & 7 & 4 \\
\hline Denmark & 39.60 & 0.461 & 5 & 6 \\
\hline Netherlands & 36.10 & 0.353 & 4 & 5 \\
\hline Germany & 36.60 & 0.384 & 3 & 1 \\
\hline Norway & 35.30 & 0.762 & 3 & 2 \\
\hline
\end{tabular}

Source: own calculations based on: [European Commission, 2014; U.S. Treasury, 2005]. 
The results of Spearman's rank correlation coefficient for data from countries with the lowest average tax rate in 2012 are as follows: the value of Spearman's correlation coefficient $\mathrm{R}$ is -1 and the value of $\mathrm{P}$ is 0 . By normal standards, the association between the two variables would be considered statistically significant. Correlation between the average tax rate in "low tax rate" countries and the GDI was negative and very strong, which means that as the average tax rate increases, the economic GDI decreases.

A correlation study was also conducted between the average tax rate and the GDI in the EU countries with the highest average tax rate and in Norway. The value of Spearman's correlation coefficient R was -0.1 and the value of $\mathrm{P}$ was 0.87289 . By normal standards, the association between the average tax rate and the GDI in "high tax rate" European countries would not be considered statistically significant.

The correlation between the number of tax brackets and the GDI was examined only for the group of countries with the highest average tax rate as the second group of EU countries are progressive-free. The value of $\mathrm{R}$ was 0.71818 and the value of $\mathrm{P}$ was 0.1718 . Thus, it must be stated that the correlation was positive, that is, with the increase in the number of tax brackets, the value of GDI increases. By normal standards, the association between the two variables would not be considered statistically significant.

\section{Conclusions}

The results of analysis lead to the general conclusion that the increase of the number of tax brackets in income progressive tax do not necessarily lead to lower GDI in the group of "high tax rate" countries. No country in this group has less than three tax brackets and GDIs were higher than in "low tax rate" EU countries. The result of Spearman's correlation did not confirm it. The value of $\mathrm{R}$ was 0.71818 and the value of $P$ was 0.1718 . Thus, it must be stated that the correlation was positive and strong, that is, with the increase in the number of tax brackets, the value of the GDI increases. But the correlation between the above two variables would not be considered statistically significant. It is difficult to assess whether a similar relationship is in selected "low tax rate" countries because there is no progressive income tax in them. Therefore, the hypothesis "the more number of tax brackets in income progressive tax, the lower the growth \& development index" has been rejected. The subject of study requires further analysis.

Spearman's correlation coefficient for variables: high average tax and GDI in countries with the highest average tax rate in 2012 was very weak and statistically insignificant and it can discourage other countries from applying many tax brackets and increasing tax rates. Interesting results have been obtained in "low taxed" EU countries. Spearman's correlation between the average tax rate in "low tax rate" countries and GDI was negative and very strong, which means that as the average 
tax rate increases, the economic GDI decreases. That correlation was statistically significant. The discussion can lead to encouraging policy makers in "low tax rate" countries to decrease tax rates as it can cause higher GDI. Spearman's correlation should be done in other EU countries with income tax progression to make sure if the correlation between the number of tax brackets an GDI is statistically significant.

Since the first Global Report on Happiness was issued, "qualitative development" has been the challenge for policy makers who can shape the future structure of the tax system across the EU countries.

The conclusions drawn in this article can be the basis for further consideration using more advanced quantitative methods and accurate data.

\section{Bibliography}

Angelopoulos K., Economides G., Kammas P., Tax-Spending Policies and Economic Growth: Theoretical Predictions and Evidence from the OECD, "European Journal of Political Economy" 2007, Vol. 23(4), DOI: https://doi.org/10.1016/j.ejpoleco.2006.10.001.

Bankman J., Griffith T., Social Welfare and the Rate Structure: A New Look at Progressive Taxation, "California Law Review" 1987, Vol. 75(6), DOI: https://doi.org/10.2307/3480545.

Capra F., Hazel H., Qualitative Growth, Sustainable Business Initiative, 2009, www.icaew.com//media/ corporate/files/technical/sustainability/qualitative-growth.ashx?la=en [access: 10.04.2017].

Castañeda A., Diaz-Gimenez J., Rios-Rull V., Earnings and Wealth Inequality and Income Taxation. Quantifying the Trade-Offs of Switching to a Proportional Income Tax in the U.S., "Working Paper Federal Reserve Bank of Cleveland" 1999, No. 9814.

Easterly W., Rebelo S., Fiscal Policy and Economic Growth, "Journal of Monetary Economics" 1993, No. 32.

Engen E.M., Skinner J., Fiscal Policy and Economic Growth, "National Bureau of Economic Research Working Paper" 1992, No. 4223.

European Commission, Taxation Trends in the European Union. Data for the EU Member States, Iceland and Norway, Eurostat Statistical Book, Brussels 2014.

Garrison C.B., Lee Y., Taxation, Aggregate Activity and Economic Growth: Further Cross-Country Evidence on Some Supply-Side Hypotheses, "Economic Inquiry" 1992, Vol. 30(1),

DOI: https://doi.org/10.1111/j.1465-7295.1992.tb01542.x.

Konopczyński M., The Impact of Taxation on Economic Growth, "Economist" 2012, No. 6.

Lee Y., Gordon R., Tax Structure and Economic Growth, "Journal of Public Economics" 2005, No. 89.

Li W., Sarte P.D., Growth Effects of Progressive Taxes by Board of Governors of the Federal Reserve System, Federal Reserve Bank of Richmond, 2001.

Mendoza E.G., Milesi-Ferretti G.M., Asea P., On the Ineffectiveness of Tax Policy in Altering Long-Run Growth: Harberger's Superneutrality Conjecture, "Journal of Public Economics" 1997, Vol. 66(1), DOI: https://doi.org/10.1016/S0047-2727(97)00011-X.

OECD, Personal income tax systems, Paris 1986.

Padovano F., Galli E., Tax Rates and Economic Growth in the OECD Countries (1950-1990), "Economic Inquiry" 2001, Vol. 39(1), DOI: https://doi.org/10.1093/ei/39.1.44.

Piketty T., Saez E., Stantcheva S., Optimal Taxation of Top Labor Incomes: A Tale of Three Elasticities, Cambridge, "National Bureau of Economic Research Working Paper" 2011, No. 17616.

Sarte P.D., Progressive Taxation in Dynamic Competitive Equilibrium, "Journal of Public Economics" 1997, Vol. 66(1), DOI: https://doi.org/10.1016/S0047-2727(97)00026-1. 
Stiglitz J., Pareto Efficient and Optimal Taxation and the New Welfare Economics, [in:] A.J. Auerbach, M. Feldstein (eds.), Handbook of Public Economics, Vol. 2, North-Holland, Amsterdam 1987, DOI: https://doi.org/10.3386/w2189.

Tanzi V., Zee H., Tax policy for emerging markets: developing countries, "National Tax Journal" 2000, Vol. 53(2), DOI: https://doi.org/10.17310/ntj.2000.2.07.

The Happiness Research Institute, The Happy Danes - Exploring the reasons behind the high levels of happiness in Denmark, 2014, www.happinessresearchinstitute.com/publications [access: 06.02.2017].

U.S. Treasury, Simple, Fair, and Pro-Growth: Proposals to Fix America's Tax System, President's Advisory Panel on Federal Tax Reform, Washington D.C. 2005, www.pordata.pt, dated on 10.07.2015.

\section{Progresja podatkowa a Indeks Wzrostu i Rozwoju (GDI)}

Głównym celem artykułu jest przedstawienie zależności korelacyjnej między średnią stawką podatkową, ilością progów podatkowych i tzw. indeksem wzrostu i rozwoju gospodarczego (GDI) w krajach wysoko opodatkowanych i nisko opodatkowanych w Europie. Postawiono hipotezę: im większa liczba progów podatkowych w podatku progresywnym od dochodów, tym niższy indeks GDI. Metody badawcze zastosowane w badaniu to unitaryzacja i analiza korelacji rang Spearmana. Zależność korelacyjna rang Spearmana między średnią stawką podatkową w krajach o niskim opodatkowaniu a GDI była negatywna i bardzo silna, co oznacza, że wraz ze wzrostem średniej stawki podatkowej GDI maleje. Korelacja ta była statystycznie istotna. Zależność korelacyjna między liczbą progów podatkowych a GDI była badana tylko w grupie krajów o najwyższej średniej stopie podatkowej, gdyż w drugiej grupie państw UE (nisko opodatkowanych) progresja podatkowa nie występuje. Była ona pozytywna i silna, co oznacza, że wraz ze wzrostem liczby progów podatkowych wzrasta wartość GDI. Jednak korelacja ta, zgodnie z przyjętymi założeniami, nie jest statystycznie istotna, dlatego hipoteza została odrzucona. Przedmiot badań wymaga dalszej analizy.

\section{Tax Progression versus Economic Growth \& Development Index (GDI)}

The main purpose of this article is to present a correlation relationship of the average tax rate, the amount of tax brackets and the so-called economic "growth \& development index" (GDI) in the "high taxed" and "low taxed" European countries. The hypothesis is as follows: the more number of tax brackets in income progressive tax, the lower the GDI. Research methods used in the study are: unity-based normalization and Spearman's rank correlation analysis. Spearman's correlation between the average tax rate in "low tax rate" countries and GDI was negative and very strong, which means that as the average tax rate increases, the GDI decreases. That correlation was statistically significant. The correlation between the number of tax brackets and the GDI was examined only for the group of countries with the highest average tax rate as the second group of EU countries are progressive-free and was positive and strong, that is, with the increase in the number of tax brackets, the value of GDI increases. But by normal standards, the association between the two variables would not be considered statistically significant. Therefore, the hypothesis has been rejected. The subject of study requires further analysis. 